Review

\title{
Leptin, the Creation of Obesity Gene and its task in Pregnancy
}

\author{
Ishrat $\mathrm{S}^{1}$, Hussain MZ ${ }^{2}$, Jahan $\mathrm{S}^{3}$
}

Leptin is a protein encoded by the 'ob' gene. Leptin is primarily produced by adipocytes and its primary physiologic function is to suppress body fat. Obese individuals have high serum leptin levels and obesity is a leptin resistant state. There are evidences that leptin levels are higher in pregnant women compared to non pregnant women. Leptin levels increase as pregnancy advances and at term, approximate those found in obese adults. There is speculation that leptin is synthesized in placenta in addition to adipose tissue mass. Leptin may have a permissive, indirect role in regulation of fetal growth.

Key Words : Leptin, Adipose tissue, Placenta, Fetus, Growth

J Bangladesh Soc Physiol.2008 Dec;(3):79-84.

For author affiliations, see end of text.

http://www.banglajol.info/index.php/JBSP

\section{What is Leptin?}

$\mathbf{T}$

The obesity gene (ob/ob) was positional cloned in 1994. The ob/ob gene product was designated as leptin. The $16 \mathrm{KD}$ proteins are derived from adipocytes. It reflects body fat content. Leptin is thought to act as an afferent satiety signal from body fat to hypothalamus. Leptin is thought to act as an afferent satiety signal from body fat to hypothalamus, causing a reduction in appetite and augmenting basal metabolic rate when fat stores are replete ${ }^{1,2}$.

In 1995, it was reported that the obese (ob/ob) mouse, which is markedly hyperphagic and obese is leptin deficient due to mutation in ob gene. When given leptin, food intake is reduced and the mice lose weight ${ }^{1}$. Genetically mediated states of leptin deficiency or resistance result in hyperphagia, obesity, preferential storage of calories as adipose tissue, infertility, susceptibility to diabetes, hypermetabolism, somatic growth impairment and elevated blood glucose concentration. In human, circulating leptin correlates with adiposity and decreases after weight loss, fasting or caloric restriction ${ }^{3}$.
Both serum leptin concentration and ob gene mRNA in adipose tissue is elevated in obese human. Moreover, there is consistent correlation between serum leptin concentration and the percentage of body fat, the BMI and basal serum insulin concentration. Human adipocytes produce more leptin when adipose tissue increases. Obese adults show decreased sensitivity to the action of leptin ${ }^{1}$.

\section{Leptin and Reproduction}

Compelling evidences suggest a possible role of leptin in reproduction; besides its central role in physiology and pathophysiology of weight gain ${ }^{4}$.

Leptin treated prepubertal mice produced at an earlier stage than did non-treated controls ${ }^{5}$. It indicates that leptin may help trigger puberty. Leptin treatment of infertile ob/ob mice restored the estrous cycle and treated females were able to become pregnant with normal pups ${ }^{6}$. Leptin dose-dependently altered insulin induced steroid production by bovine ovarian granulose ${ }^{7}$ and theca cell ${ }^{8}$. Leptin stimulates gonadotrapin release in rhesus monkeys ${ }^{9}$.

In the human mRNA transcripts for both leptin and its receptor are expressed in pre ovuolatory 
follicles. Leptin receptor expressions were located in granulosa and theca cell populations 10. Increases in peripheral levels of leptin are associated with onset of menarche. A woman of reproductive age typically exhibits higher levels of leptin than men of comparable age or adiposity 12. This unique gender dichotomy extends to adolescents as well. Peripheral levels in girls, although not in boys are highly predictive of gains in adipose mass and the inhibition of puberty ${ }^{13}$. Similarly leptin levels in cycling women have been reported by some investigators to be greater than those in post-menopausal women ${ }^{14}$. Circulating levels of the polypeptide in female neonates ${ }^{15}$ and fetuses in utero are higher than their male counterparts, further implying a relationship with female reproductive development.

However, female patients with lipotrophic diabetes, who have chronic low levels of leptin from early pregnancy developed normal reproductive function at puberty and maintained normal menstrual cycles ${ }^{16}$. Anorectic women who have very low levels of leptin are also amenorrhoeic. These findings suggest that leptin has a permissive rather than a fundamental role in female reproduction.

\section{Leptin as a gestational hormone}

During pregnancy, maternal leptin that arise from adipose tissue stores and placenta increase with advancing gestational age. Proposed physiological roles for leptin in pregnancy include regulation of conceptus growth and development, fetal and placental angiogenesis, embryonic haematopoiesis and hormone biosynthesis within the maternal fetoplacental unit. The specific localization of both leptin and its receptor in the syncytiotrophablast implies autocrine and/or paracrine relationship in this endocrinologically active tissue ${ }^{4}$.

In the pregnant rodents (rat and mouse) serum leptin levels are many fold higher than non pregnant ones ${ }^{17}$. Leptin and leptin receptor transcripts are expressed in various tissues including the uterus, placenta and maternal adipose tissue ${ }^{18}$. Removal of conceptus via hysterectomy results in premature decrease in serum leptin, indicating an important role of the fetoplacental unit in maintaining elevated serum leptin levels ${ }^{17}$. Expression of leptin receptor transcripts were detected in placental villous tissue (almost exclusively the layer of syncytiotrophablast), corpus lutium, decidua, amnio-chorion as well as maternal omental and subcutaneous adipose tissue collected from baboons ${ }^{19}$.

In human pregnancy, serum leptin is continuously increased from 6-8 weeks up-to 38-40 weeks of pregnancy ${ }^{20}$. The high level of leptin during second and third trimester is not associated with decreased food intake or reduced metabolic activity. Therefore a state of leptin resistance is indicated that is compared to that which occurs in obesity. High levels of leptin during pregnancy might lead to uncoupling of eating behavior to fill up fat stores and to relative unresponsiveness of leptin receptor. This unresponsiveness could ensure additional energy stores and thus prepare women for stress during birth and provide for adequate lactation thereafter ${ }^{6}$.

Serum leptin decrease dramatically after birth ${ }^{20}$. A reduction in serum leptin levels has been observed in women suffering from spontaneous abortion during first trimester ${ }^{21}$.

\section{Leptin and maternal body fat mass}

Changes in circulating leptin levels in pregnancy correlates positively with changes in weight, body mass index, fat mass and percentage fat mass in pregnancy 22, 23, 24. Women who gained more during pregnancy had higher leptin levels. Similarly, women who gained or failed to lose weight postpartum had higher leptin levels. Leptin per unit fat mass was significantly more elevated at 36 weeks pregnancy than that at 3 and $6 \mathrm{~m}$ postpartum ${ }^{25}$.

However energy expenditure and adipose weight gain are insensitive to increased leptin levels

J Bangladesh Soc Physiol. 2008 Dec;(3):79-84 
suggesting resistance to leptin action. These could be secondarily either due to reduced sensitivity at the level of hypothalamus or due to increased concentration of leptin binding protein causing reduced bioactivity 23,25 .

\section{Leptin and placenta}

Plasma leptin levels in pregnant women are higher than those in body mass index matched non-pregnant women and have less correlation with body mass index ${ }^{26}$. A significant increase in circulating leptin with little or no change, (or in some cases, decrease) in fat mass in early pregnancy are further evidence that factors other than adipose tissue are responsible for increased leptin during pregnancy 27.

Elevated plasma leptin levels in pregnant women rapidly decrease after placental delivery to those levels in body mass index matched non-pregnant women. This indicates that placenta is a significant source of maternal leptin. Leptin levels in cord vessels are markedly lower than those in maternal veins. Leptin with a molecular weight of 1600, probably does not cross placental barrier. Cord blood leptin significantly correlates with placental weight and birth weight. There is a positive umbilical venous arterial difference in leptin level. All evidences suggest that leptin is secreted from placenta into fetoplacental circulation ${ }^{26}$.

Specific leptin and leptin receptor transcripts were determined by various methods in trophoblastic cells of placenta ${ }^{26,28}$. It was suggested that placenta functions as an endocrine organ capable of secreting leptin. There is a study 29 which indicates a positive correlation of estrogen and human chorionic gonadotropin (hCG) with leptin in pregnancy and enhanced release of leptin from in-vitro culture of trophoblast on addition of recombinant hCG. So there may be regulatory associations of leptin with placental steroid and polypeptide hormones for pregnancy maintenance. This potential may lend further significance to the report that leptin levels in women suffering spontaneous abortion in first trimester were $35 \%$ lower $(\mathrm{P}<0.001)$ than in women who successfully maintained their pregnancies ${ }^{23}$.

\section{Leptin and fetal growth}

The physiological role most commonly postulated for leptin during pregnancy involve the regulation of fetal growth and conceptus development ${ }^{4}$. Leptin is present in fetal cord blood at the end of first half of gestation ${ }^{2}$. Immuno-histochemical staining of developing subcutaneous tissues of human embryos at 6-10 weeks gestation indicates that leptin is produced by developing fat cells from the beginning of lipidogenesis and differentiation ${ }^{30}$. Levels in umbilical cord at term are highly correlated with birth weight ${ }^{1,2,22,24,27,31-35}$. Although placenta appears to be an important source of leptin, some suggest that fetal adipose tissue is the main contributor to fetal leptin concentrations ${ }^{2,31}$.

Significant correlation exists between birth weight, birth length, head circumference, ponderal index, placental weight, cord blood insulin and leptin concentrations in cord blood at birth ${ }^{32}$. Therefore, intrauterine growth could be correlated with fetal and maternal leptin levels. Newborns that are large for gestational age have higher leptin levels than do that are appropriate for gestational age or small for gestational age 32,36 . In a multivariate stepwise regression analysis ${ }^{33}$, only the intrauterine growth status remained independently associated with cord blood leptin when data were adjusted for birth weight, birth length, placental weight, maternal serum leptin, cord blood insulin and intrauterine growth status. These data from the literature suggest a role for leptin as regulator of fetal growth.

The relationship between growth status and leptin may be indirect and mediated through other factors like fetal insulin and insulin like growth factor ${ }^{33}, 36$. Leptin in cord blood originating in the placenta and/or fetus may potentiate growth 
by modulating growth hormone secretion ${ }^{37}$. Leptin receptive mRNA has been identified in human fetal anterior pituitary and leptin administration specifically stimulated GH secretion from primary human fetal pituitary cultures without affecting ACTH, prolactin or gonadotropin secretion ${ }^{38}$.

Leptin has been proposed as a regulator of haematopoiesis ${ }^{39}$ and angiogenesis ${ }^{40}$ in different development models. Probable role of leptin in haematogenesis and angiogenesis also reinforce the idea of its putative role in fetal growth.

A significant association between fetal and maternal leptin were described ${ }^{32,34,35}$. Leptin may thus be able to cross the placental barrier and link the nutritional status of the mother with that of the fetus intimately.

\section{Conclusion}

There are many descriptive evidences that suggest a regulatory and permissive role of leptin in the course and outcome of pregnancy. However, further studies are needed to support the assumption that placenta is a major determinant of leptin in fetomaternal circulation and leptin might serve as a diagnostic and therapeutic tool in obstetrics.

\section{Author Affiliations}

1. *Dr Shakeela Ishrat, Junior Consultant of Gynecology \& Obstetrics, Brahmanbaria Sadar Hospital Brahmanbaria

2. Dr Md Zahid Hussain, Associate Professor of Pediatrics, Bangabandhu Sheikh Mujib Medical University

Shahbagh, Dhaka.

3. Professor Sultana Jahan, Chairman and Head (Ex), Department of Gynecology \& Obstetrics, Bangabandhu Sheikh Mujib Medical University, Shahbagh, Dhaka

* Forcorrespondance

\section{References}

1. Shekhawat PS, Garland JS, Sheepuri C, Mick GJ, Shoshidharan P, Pets CJ et al. Neonatal cord blood leptin: its relationship to birth weight, body mass index, maternal diabetes and steroids. Pediatr Res. 1998; 43: 338-343.
2. Jaguet D, Leiger J, Levy Marchal O, Oury JF, Czernichow P. Ontogeny of leptin in human fetuses and new born: effect of intrauterine growth retardation on serum leptin concentration. J Clin Endocrinol Metab. 1998; 89: 1243-1246.

3. Rosenbuam M, Liebel RL. The role of leptin in human physiology. N Engl J Med. 1999; 341: 913-914.

4. Henson MC, Castracane VD. Leptin in pregnancy. Biol Reprod. 2000; 63: 1219-1228.

5. Chehab PF, Mounzch K, Lu R, Lim ME. Early onset of reproductive function in normal female mouse treated with leptin. Science. 1997; 275: 85-90.

6. Kratzsch J, Hockel M, Kiess W. Leptin and pregnancy outcome. Curr Opin Obstet Gynecol. 2000; 12: 501505.

7. Spicer LJ, Francisco CC. The adipose obese gene product, leptin: evidence of a direct inhibitory role in ovarian function. Endocrinology. 1997; 138: 33743379.

8. Spicer LJ, Francisco CC. Adipose obese gene product, leptin inhibits bovine ovarian, theca cell steroidogenesis. Biol Reprod. 1998; 58: 207-212.

9. Finn PD, Cunningham MJ, Pan K-YF, Spies HG, Clifton DK, Steiner RA. The stimulatory effect of leptin on the neuroendocrine reproduction axis of the monkey. Endocrinology. 1998; 139: 4652-4662.

10. Agarwal SK, Vogel K, Weitsman SR, Mayoflow DA. Leptin antagonises insulin like growth factor augmentation of steroidogenesis in granuloma and theca cells of the human ovary. J Clin Endocrinol Metab. 1999; 84: 1072-1076.

11. Matkovic V, Ittich JZ, Skugar M, Badenhap JE, Goel $\mathrm{P}$, Clairmont $\mathrm{A}$ et al. Leptin is inversely related to age at menarche in human females. J Clin Endocrinol Metab. 1997; 82:3239-3245.

12. Castracane VD, Kraemer RR, Franken MA, Kraemer GR, Gempel T. Serum leptin concentration in women: effect of age, obesity and estrogen administration. Fertil Steril. 1998; 70: 472-477.

13. Ahmed ML, Ong KKL, Marrell DJ, Cox L, Drayer N, Perry L et al. Longitudinal study of leptin concentration during puberty: sex differences and relationship to changes in body composition. J Clin Encocrinol Metab. 1999; 84: 899-905.

14. Shemizu H, Shimomura Y, Nakanuhi Y, Futawatas T, Oohtani $\mathrm{K}$, Sato $\mathrm{N}$ et al. Estrogen increases in vivo leptin production in rats and human subjects. J Endocrinol. 1997; 154: 285-292.

J Bangladesh Soc Physiol. 2008 Dec;(3):79-84 
15. Matsuda J, Yokoto I, Iida M, Murakami T, Naito E, Ito $\mathrm{M}$ et al. Serum leptin concentration in cord blood: relationship to birth weight and gender. J Clin Endocrinol Metab. 1997; 82: 1642-1644.

16. Andreelli F, Haraire-Brouten H, Laville M, Tauber JP, Riou JP, Thevolet C. Normal reproductive function in leptin deficient patients with lipotropic diabetes. J Clin Endocrinol Metab. 2000; 85: 715-719.

17. Hoggard N, Hunter L, Lea RG, Trayhurn P, Mereer JG. Ontogeny of the expression of leptin and its receptor in the murine fetus and placenta. Br J Nutr. 2000; 83: 317-326.

18. Garcia MDE, Casaneuva FF, Dieguer C, Senaris RM. Gestational profile of leptin messenger ribonucleic acid (mRNA) content in the placenta and adipose tissue in the rat and regulation of the mRNA levels of the leptin acceptor subtypes in the hypothalamus during pregnancy and lactation. Biol Reprod. 2000; 62: 698703.

19. Henson MC, Castracane VD, O’Neil JS, Gimpel T, Swan KF, Green AH et al. Serum leptin concentrations and expression of leptin transcripts in placental trophoblast with advancing baboon pregnancy. J Clin Endocrinol Metab. 1999; 84: 2543-2549.

20. Schubrino C, Kiess W, Englaro P, Roscher W, Dotsch $\mathrm{J}$, Hanitsch $\mathrm{S}$ et al. Levels of leptin in maternal serum amniotic fluid and arterial and venous cord blood: relation to neonatal and placental weight. J Clin Endocrinol Metab. 1997; 82: 1480-1483.

21. Lage M, Garcia Mayer RJ, Tome MA, Cardido F, Valle Inelan F, Considene RV et al. Serum leptin levels in women throughout pregnancy and the postpartum period and in women suffering spontaneous abortion. Clin Endocrinol. 1999; 50: 211-216.

22. Geary M, Pringle PJ, Persaud M, Wilshin J, Hindmarsh PS, Rodel CH et al. Leptin concentration in maternal serum and cord blood: relationship to maternal anthropometry and fetal growth. Br J Obstet Gynaecol. 1999; 106: 1054-1060.

23. Sattar N, Greer IA, Perwani I, Gibson J, Wallace M. Leptin level in human pregnancy: marker for fat accumulation and mobilization? Acta Obstet Gynaecol Scand. 1998; 77: 278-283.

24. Lakhao GR, Nazir K, Chundigar T, Jabeen N, Qureshi NA. Serum leptin levels in pregnant Pakistani females: relationship with body mass index and placental weight. J Pak Med Assoc. 2001; 51: 32-36.

J Bangladesh Soc Physiol. 2008 Dec;(3):79-84
25. Butt NF, Hopkinson JM, Nicolson MA. Leptin in human reproduction: serum leptin levels in pregnant and lactating women. J Clin Endocrinol Metab. 1997; 82: 585-589.

26. Yura S, Sagawa N, Mise H, Mori T, Masuzaki H, Ogawa $\mathrm{Y}$ et al. A positive umbilical venous arterial difference of leptin level and its rapid decline after birth. Am J Obstet Gynaecol. 1998; 178: 926-930.

27. Highman TJ, Friedman JE, Huston LP, Wong WW, Catalano PM. Longitudinal changes in maternal serum leptin concentration, body composition and resting metabolic rate in pregnancy. Am J Obstet Gynaecol. 1998; 178: 1010-1015.

28. Jakimuk AJ, Skalba P, Hulerski D, Tarkowaski R, Haezynski J, Magoffia DA. Leptin messenger ribonucleic acid (mRNA) content in human placenta at term: relationship to levels in cord blood and placental weight. Gynaecol Endocrinol. 2003; 17(4): 311-336.

29. Chardonnens D, Cameo P, Aubert ML, Pralong FP, Islam D, Campana A et al. Modulation of human cytotrophoblastic leptin secretion by interleukin alpha and beta oestrodiol and its effect on HCG secretion. Mol Hum Reprod. 1999; 5: 1077-1082.

30. Atarassova P, Papova L. Leptin expressed during the differentiation of subcutaneous adipose cells of human embryos in situ. Cells Tissues Organ. 2000; 166: 1519.

31. Schulbring C, Kiess W, Englaro P, Roscher W, Datsch J, Hanitsch $\mathrm{S}$ et al. Levels of leptin in maternal serum, amniotic fluid and arterial and venous cord blood: relation to neonatal and placental weight.

32. Varvargou A, Manatzoros CS, Beratis NG. Cord blood leptin concentration in relation to intrauterine growth. Clin Endocrinol. 1999; 50: 177-183.

33. Manderson JG, Pattison CC, Hadden DR, Traub AJ, Leslic H, Medonee DR. Leptin concentrations in maternal serum and cord blood in diabetic and nondiabetic pregnancy. Am J Obstet Gynaecol. 2003; 188(6): 1326-1332.

34. Tamura T, Goldenberg RL, Johnston RE, Cliver SP. Serum leptin concentrations during pregnancy and their relationship to fetal growth. Obstet Gynaecol. 1998; 91: 389-95.

35. Babay ZA, Warey AS, El Hazmi MA, Addar MH. Leptin level in pregnant mothers at term and cord blood and the effect of newborn gender. Saudi Med J. 2004, 25: 212-214. 
Review

36. Wolf HS, Ebenbichler CF, Huter O. Fetal leptin and insulin levels only correlate in large for gestational age infants. Eur J Endocrinol. 2000; 142: 623-627.

37. Ochva R, Zarate A, Hernandez M, Galvan R, Basurta L. Serum leptin and somatotropin components correlate with neonatal birth weight. Gynaecol Obstet Invest. 2001; 52(4): 243-247.

38. Shimon I, Yan Y, Magoffin DA, Friedman PC, Melmed S. Intact leptin receptor is selectively expressed in
Leptin in Pregnancy

human fetal pituitary and pituitary adenomas and signal human fetal pituitary growth hormone secretion. J Clin Endocrinol Metab. 1998; 83: 4059-4064.

39. Bennette BD, Solar GP, Yuan JG, Mathias J, Thomas GR, Mathews W. A role for leptin and its cognate receptor in haematopoiesis . Curr Biol. 1996; 6: 11701180

40. Bouloumic A, Drexler HCA, Lafontan M, Busse R. Leptin the product of ob gene promotes angiogenesis. Circ Res. 1998; 83: 1059-1066. 